\title{
TNFRSF13C wt Allele
}

National Cancer Institute

\section{Source}

National Cancer Institute. TNFRSF13C wt Allele. NCI Thesaurus. Code C111796.

Human TNFRSF13C wild-type allele is located within 22q13.1-q13.31 and is approximately $2 \mathrm{~kb}$ in length. This allele, which encodes tumor necrosis factor receptor superfamily member $13 \mathrm{C}$ protein, is involved in promoting peripheral B-cell survival. Mutations in this gene are associated with common variable immunodeficiency-4. 